\title{
EFFECT OF ADJUVANTS ON THE AMOUNT OF AIR INCLUDED IN DROPLETS GENERATED BY SPRAY NOZZLES
}

\section{ALISSON A. B. MOTA ${ }^{1}$, ULISSES R. ANTUNIASSI ${ }^{2}$, RODOLFO G. CHECHETTO ${ }^{1}$, RONE B. DE OLIVEIRA ${ }^{3}$, ANNE C. A. E SILVA ${ }^{1}$}

\begin{abstract}
The air included in droplets generated by spray nozzles directly int0erferes in transport, deposition and retention of the droplets after its impact on the target. The objective of this study was to analyze the interference of adjuvants in the amount of air included in droplets generated by spray nozzles. The treatments were composed by four spray solutions containing mineral oil, vegetable oil, surfactant and water, and three spray nozzles, two air induction type and one pre-orifice. The air included was calculated by the difference between the volume of spray mix (air plus liquid) and only the liquid, which was made by means of sprayed samples captured in a funnel and collected in a graduated cylinder. The surface tension was estimated by the gravimetric method using a precision scale and a graduated pipette. The surfactant provided the largest percentage of air included in the spray. For the surface tension, the mineral oil and the surfactant had the lowest values. It was concluded that the use of adjuvants had a direct influence on the percentage of air included. In addition, products with greater ability to reduce surface tension and to form homogeneous solutions provided the increase in the percentage of air included in the droplet.
\end{abstract}

KEYWORDS: application technology, air induction, pre-orifice, surface tension.

\section{INFLUÊNCIA DE ADJUVANTES NA QUANTIDADE DE AR INCLUÍDO EM GOTAS GERADAS POR PONTAS DE PULVERIZAÇÃO}

RESUMO: $\mathrm{O}$ ar incluído em gotas geradas por pontas de pulverização interfere diretamente em seu transporte e deposição, influenciando também na retenção das mesmas após o impacto no alvo. O objetivo deste trabalho foi verificar a interferência de adjuvantes na quantidade de ar incluído em gotas geradas por pontas de pulverização. Os tratamentos utilizados corresponderam a soluções contendo: óleo mineral, óleo vegetal, surfatante e água, aplicados com três tipos de pontas de pulverização, sendo duas com indução de ar e uma com pré-orifício. O ar incluído foi calculado através da diferença entre o volume da mistura pulverizada (ar mais líquido) e apenas o líquido, que foi feito por meio de amostras pulverizadas, capturadas em um funil e coletadas em proveta graduada. A tensão superficial foi estimada através do método gravimétrico, utilizando uma balança de precisão e uma bureta graduada. O surfatante foi o que proporcionou maior porcentagem de ar incluído na pulverização. Para a tensão superficial, as caldas contendo óleo mineral e o surfatante tiveram os menores valores. Os resultados mostraram que o uso de adjuvantes tem influência direta na porcentagem de ar incluído. Além disso, adjuvantes com maior capacidade de redução da tensão superficial e que formam misturas mais homogêneas proporcionaram aumento da porcentagem de ar incluído nas gotas pulverizadas.

PALAVRAS-CHAVE: tecnologia de aplicação, indução de ar, pré-orifício, tensão superficial.

\section{INTRODUCTION}

Improper use of pesticides have caused concern because of the risk of environmental contamination; been the drift the main loss that can cause this contamination (COSTA et al., 2007).

\footnotetext{
${ }^{1}$ Doutorando, Depto. de Engenharia Rural, FCA/UNESP - Botucatu/SP, alisson_abm@hotmail.com, rgchechetto@hotmail.com, caroline.arruda@yahoo.com.br.

${ }^{2}$ Professor Titular, Depto. de Engenharia Rural, FCA/UNESP - Faculdade de Ciências Agronômicas/Universidade Estadual Paulista, Botucatu/SP, ulisses@fca.unesp.br.

${ }^{3}$ Prof. Dr. Adjunto da Universidade Estadual do Norte do Paraná-UENP, Bandeirantes/PR, rone@uenp.edu.br.

Recebido pelo Conselho Editorial em: 19-11-2012
}

Aprovado pelo Conselho Editorial em: 27-5-2013

Eng. Agríc., Jaboticabal, v.33, n.6, p.1281-1288, nov./dez. 2013 
The use of air induction tip is an established Drift Reduction Technique (TRD), and confirmed by several studies (COSTA et al., 2007; BALAN et al., 2008; CARVALHO et al., 2011; COSTA et al., 2012). According to MATTHEWS (2007) and GULER et al. (2007), this occurs because this type of tip produces a droplet spectrum with higher median volume diameter (MVD ), and reduces the volumetric percentage of droplets more likely to drift (less than $100 \mu \mathrm{m}$ ) . CHECHETTO \& ANTUNIASSI (2012) and CUNHA et al. (2010) have noted this change in the droplet spectrum caused by this type of tip. In addition, air induction tip stand out from the others in form droplets with large amounts of air bubbles inside, called air inclusions.

Ends without the air induction system may also produce droplets with air inclusions. BUTLER ELLIS et al. (1997) reported the presence of bubbles in a jet plane ends without inducing air which becomes trapped in droplets at the time of formation of the spray. Moreover, the authors reported that the amount of air added is dependent on the type of solution which, homogeneous solutions tend to include more air than heterogeneous solutions.

The air inside the droplets is very important for the retention when impact with a surface. Large droplets generally tend to suffer the effect of rebound when they hit a surface; however, the air included helps to reduce this effect, with similar results to a spray made with smaller droplets (MILLER \& BUTLE ELLIS, 2000). Another important feature of air inclusions is that these improve the spread of droplets when reaching a surface, increasing the coverage of the target (MILLER \& BUTLER ELLIS, 2000; BOLLER \& RAETANO, 2010).

The tip air induction, by producing larger droplets DMV when compared to conventional tip are recommended primarily for applications that do not required high levels of coverage or penetration of the crop canopy, as for applications of herbicides of systemic action as glyphosate and 2,4 D. However, according to MATTHEWS (2007), one of the ways to improve the penetration of droplets into the canopy to the plants for this type of tip is the use of air assistance on the bar, especially in cereal crops.

In addition to the air induction, adjuvant has also been used to reduce the risk of drift. ANTUNIASSI \& BAIO (2008) alerted for problems related to improper use of adjuvants by unawareness of their actions, which can harm the action of the plant health product, or even these adjuvants may not cause significant effects, making them unnecessary. The authors illustrate the process of formation of droplets by the spray tip may be changed according to the physical characteristics of the solution, so changes according to the used adjuvant. The surface tension of the solution is one of those characteristics, which according to CUNHA \& BUENO (2010) is directly related to the process of droplet formation. According to CHRISTOFOLETTI (1999), solutions with low surface tension values have greater ease of forming droplets with reduced sizes. The use of some adjuvant have direct influence on the surface tension of the solution, as demonstrated in a study by IOST \& RAETANO (2010) MONTÓRIO et al. (2005) and OLIVEIRA \& ANTUNIASSI (2012), also FAGGION (2002) mentions that the addition of adjuvant in tip with air induction contributes to better stability of droplets generated, which maintains the structure of the droplets with air inside for a longer period. Moreover, MILLER \& BUTLER ELLIS (2000) indicated that the behavior of adjuvant is quite variable, according to each spray tip, especially in air induction tip sensitive to which are more sensitive to changes caused by the spray adjuvant.

Considering the importance of air inclusions, modifications that adjuvant can cause in the physical characteristics of the solution and the formation of spray droplets, the objective of this study was to evaluate the influence of adjuvant and conditions of those affected by surface tension at the air quantity included in droplets generated by different spray tip.

\section{MATERIALS AND METHODS}

The treatments consisted of three models of tip (new) four solutions, totaling twelve treatments. Two spray tips were models with air induction (Ultra Lo-Drift - ULD and Guardian Air - GA), both manufactured by Hypro, and one with a pre-hole (Model Drift Guard - DG), 
manufactured by the Spraying Systems. The entire tip has been selected with jet plane 1100 and nominal flow rate of $1.14 \mathrm{~L}$ min-1 (0.3 gal min-1). The solution used corresponded to three solutions containing adjuvant for agricultural use and only one with water. The characteristics and doses of adjuvant are described in Table 1.

TABLE 1. Adjuvant description and abbreviations used for the treatment characterization.

\begin{tabular}{lllll}
\hline Trade name & Principal Componente * & Manufator & $\begin{array}{l}\text { Dose } \\
* *\end{array}$ & Abbreviation \\
\hline Nimbus & Mineral oil & Syngenta & 0,50 & NB \\
Vegetal oil Nortox & Vegetal oil & Nortox & 1,25 & OVN \\
Agral & Nonil fenoxi poli etanol & Syngenta & 0,10 & AG \\
\hline
\end{tabular}

* According to information provided by the manufacturers. **Doses selected according to the positioning of the products by the companies and may differ from recommendations contained in the leaflets.

To determine the amount of air included in the droplets, a methodology was proposed by FAGGION (2002). It was mounted on a structure consisting of a funnel of flexible material (polivinilcarbonate) with dimensions of $0.98 \mathrm{~m}$ in top opening diameter, $1.00 \mathrm{~m}$ high and $0.02 \mathrm{~m}$ in diameter at the bottom opening. The funnel was suspended by a metal frame. For spray, tip was mounted on this structure perpendicularly to the same level as the upper opening at the center of the funnel, so that the entire spray tip solution was captured by the funnel (Figure 1).

The sprayed solution captured in the funnel was collected using a graduated cylinder with a capacity of $250 \mathrm{~mL}$, which for each sample, was positioned below the lower orifice of the funnel being closed with the collecting beaker removed from the flow, which was made when the liquid reached approximately three quarters (3/4) of the volume of the cylinder. For each collection it is paid attention to the liquid trickling down the funnel directed by the edges of the cylinder that wouldn't impact directly with the background, avoiding foaming due to this impact.

Immediately after collection of each sample, the reading of the volume contained within the cylinder corresponding to the liquid mixture produced in the air spray was performed. The reading was done by taking the base line between the homogeneous part of the liquid and foam, as shown in Figure 1. After reading proceeded and weigh the volume contained in the tube, on the balance of 0.01 g accuracy.

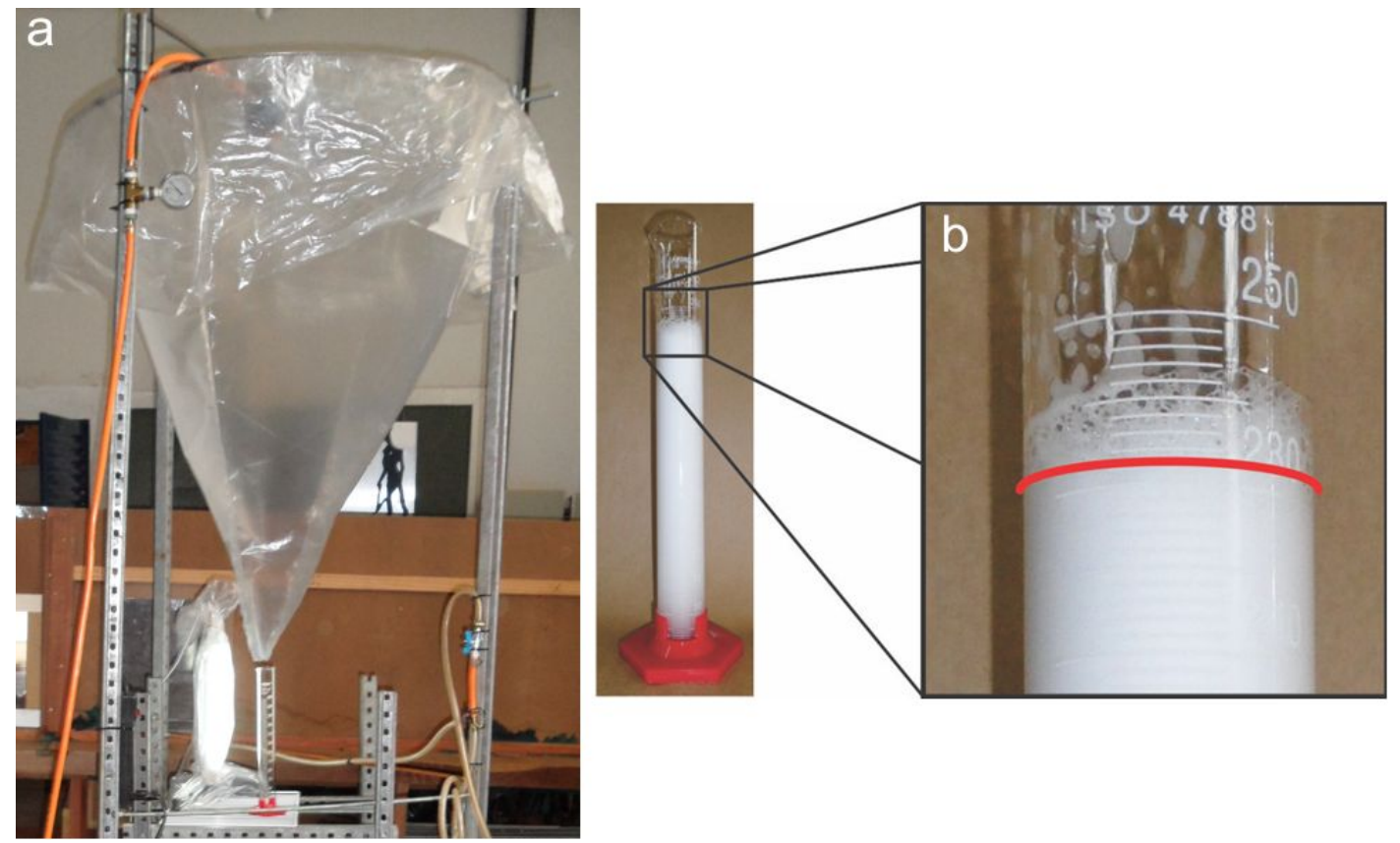

FIGURE 1. Structure for capture the air included in drops (a) and collecting the spray detail, indicating the point where it was read the volume inside the cylinder (b). 
Prior to testing, the determination of the density of the solution in which all corresponded to 1 $\mathrm{g} \mathrm{cm}-3$ with temperature of the solution and environment of $270 \mathrm{C}$, and this was the same temperature as the other tests were performed. The reading in $\mathrm{mL}$ beaker made corresponded to the volume of the mixture of liquid and air. The mass in grams, observed on the scales only corresponding to the volume of liquid, and this value can be directly interpreted as the volume in milliliters, due to the density of all the solution be $1 \mathrm{~g} \mathrm{~cm}-3$.

Knowing the liquid volume collected, and the air volume of the mixture after spraying, the data were related, allowing the volumetric percentages were calculated from the captured air with liquid each repetition using Equation 1.

$$
\operatorname{Ar}(\%)=(\mathrm{Vm}-\mathrm{V} 1) / \mathrm{Vm} * 100
$$

In that

$\operatorname{Ar}(\%)$ - the percentage volumetric air;

Vm - Volume of mixing $\mathrm{mL}$,

$\mathrm{Vl}$ - Volume of the liquid, mL.

The surface tension of each solution was estimated according to the methodology developed by COSTA (1997), in which values are determined by the gravimetric method, in which a set of mass 25 drops was estimated (and this set of droplets corresponding to a 25 repetition) in an analytical balance accurate to $0.1 \mathrm{mg}$. The drops were generated by means of a $25 \mathrm{~mL}$ burette, wherein a valve has been set to dispense each drop in a range of $25 \mathrm{~s}$. The beads were placed in a beaker placed on the balance, where the distance between the bottom of the beaker and the burette was $5 \mathrm{~cm}$. Weight data were converted into droplets surface tension, assuming an average weight of drops of distilled water at $72.6 \mathrm{mN} \mathrm{m}^{-1}$.

For all analyzes four replicates were performed, and the results for the different adjuvant and tip compared by confidence interval for the differences between the ratings at 95\% probability. The correlations between the surface tension and the percentage of included air through the Pearson coefficient at 5\% probability were also made.

\section{RESULTS AND DISCUSSION}

The results of volumetric percentage of air included in the spraying (\% air included) are shown in Figure 2. For all nozzles studied the performance of different adjuvant was similar, with the adjuvant-based surfactant (nonyl phenoxy poly ethanol) gave the highest percentage of air included in the spray, followed by oil-based adjuvant, Nimbus (mineral oil ) and Vegetable Oil Nortox, and that the water resulted in the lowest percentage BUTLER ELLIS et al. (1997) achieved similar results by observing photos taken on captured droplets of the silicone-based fluid the addition of an adjuvant surfactant, polyoxyethylene amine base grease has led to increased inclusion of air bubbles in the droplets. The same behavior was not observed in the lecithin-based adjuvant and propionic acid or water only, and although there inclusions were few compared to the surfactant.

There were also differences between the spray nozzles, which for all the solution the tip Ultra Lo-Drift (ULD) had the highest values of percentage of air included, followed by the tip Guardian Air (GA) and Drift Guard (DG). These results are in agreement with the study by FAGGION \& ANTUNIASSI (2010), in which the highest values were observed for the tip with the air induction system. However, the authors presented an average value of $21.51 \%$ of the captured air to the tip with air induction, whereas in this study, the highest value observed was $12.76 \%$. It is noteworthy, however, that models of tip used in the two studies were different, being studied by FAGGION \& ANTUNIASSI (2010) to model Air Induction manufactured by Spraying Systems. 


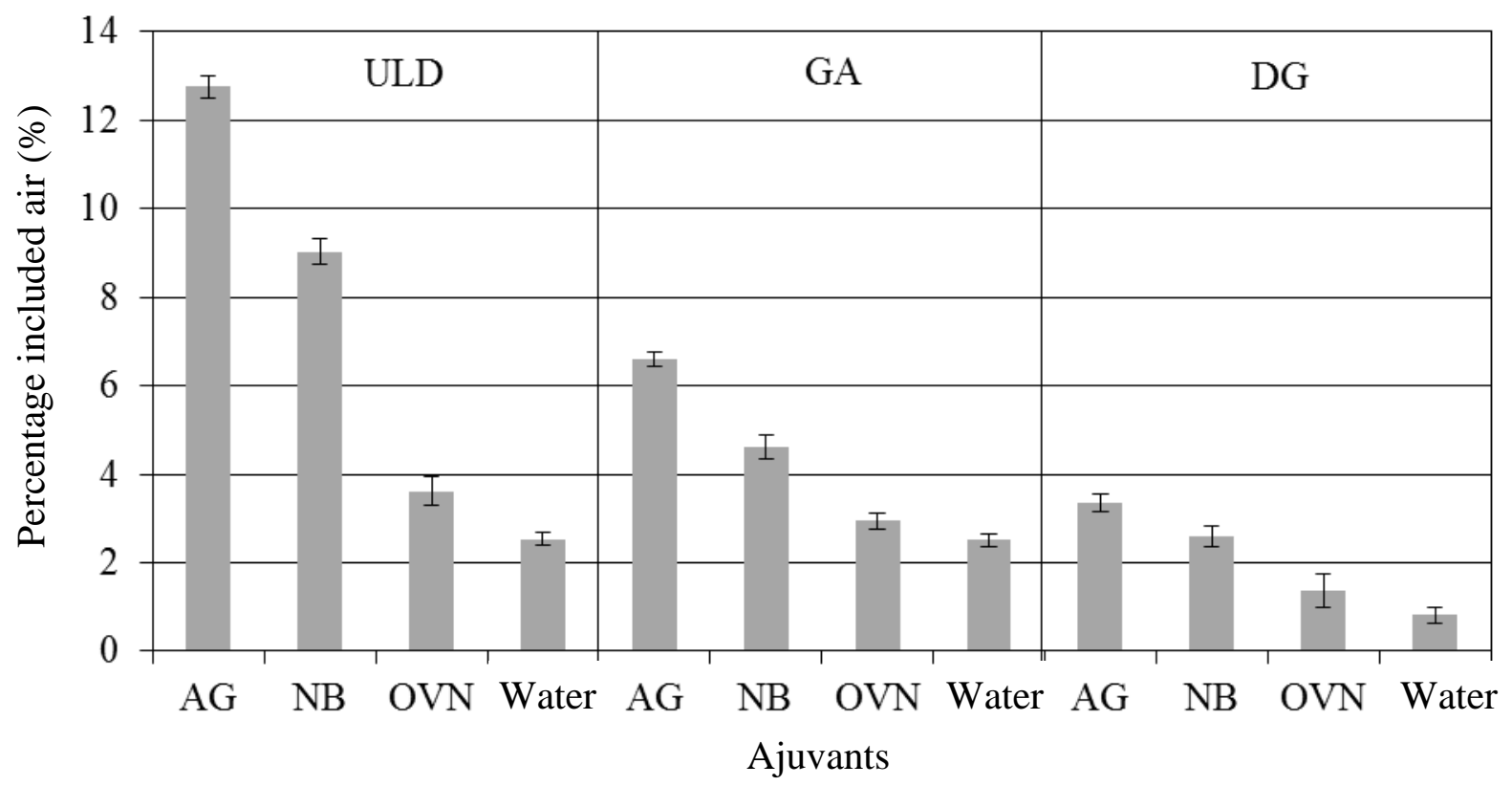

FIGURE 2. Included air percent (means \pm IC5\%) for spray different adjuvants according to the nozzles Ultra Lo-Drift (ULD), Guardian Air (GA) and Drift Guard (DG).

For values of surface tension was observed that all adjuvant decreased stress relative to pure water, of which the adjuvant Agral and Nimbus had lower values: 29.72 and $31.73 \mathrm{mN} \mathrm{m}^{-1}$ respectively, did not differing from each other, but differing from vegetable oil Nortox and water. OLIVEIRA (2011) also obtained similar results in all reviews adjuvant decreased the surface tension relative to water, including the Nimbus and Agral, the same concentrations of this work. For Vegetable Oil Nortox, MENDONÇA et al. (2007) obtained a very similar result, working with the adjuvant in the same concentration of $1 \% \mathrm{v} \mathrm{v}-1$, the surface tension was $51.89 \mathrm{mN} \mathrm{m}^{-1}$ in the present study was $56.66 \mathrm{mN} \mathrm{m}^{-1}$.

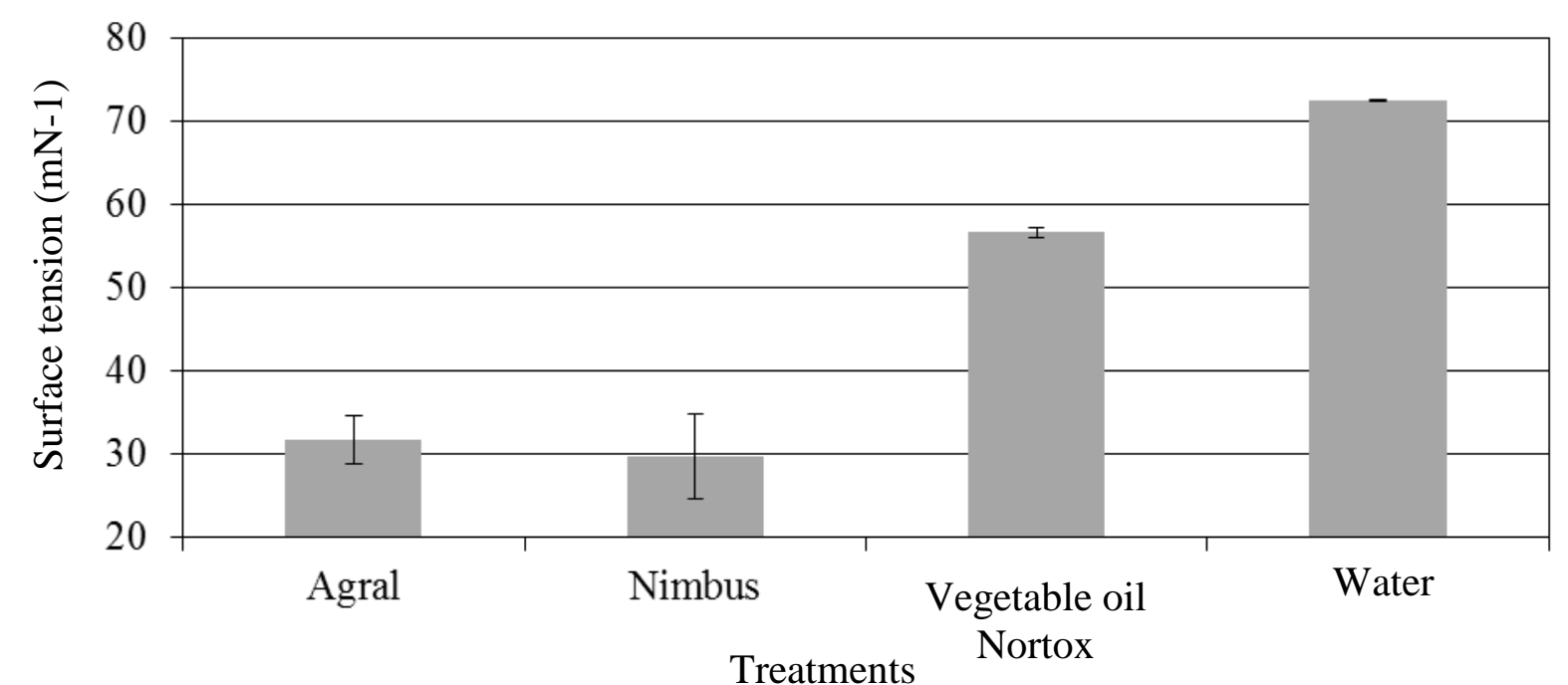

FIGURE 3. Surface tension values (means \pm IC5\%) of spray solution containing different adjuvant.

In all spray nozzles studied correlations between surface tension and percentage of air included were observed, which were negative, the decrease in surface tension caused the increase of the percentage of air (Figure 4). According to MCMULLAN (2000), adjuvant that has ability to reduce the surface tension of a solution is directly related to the air that is incorporated into the solution , because it facilitates the entry of air bubbles in the liquid, forming an emulsion of air over liquid or foam . Just as solutions with these characteristics are predisposed to foam, have ease of incorporation of air in droplets generated by spray nozzles, especially those with air induction 
system. This fact is explained by the very functioning of air induction tip , which according PIGGOTT \& MATTHEWS (1999), emerged from the enhancement of calls generating foam tip , which are used to demarcate the spray tracks .

The adjuvant Agral had shown in the entire tip higher capacity if retaining air in the sprayed droplets. However, the values of surface tension of the surfactant and the mineral oil showed no statistical difference when compared. According to OLIVEIRA (2011), the Agral and Nimbus if analyzed only by the surface tension, could be classified in the same functional group. This indicates that the variation of surface tension is not the only variable which affects the amount of air included. Otherwise, the amount of air included in one end using both the adjuvant Agral as Nimbus should have similar values, which did not occur.

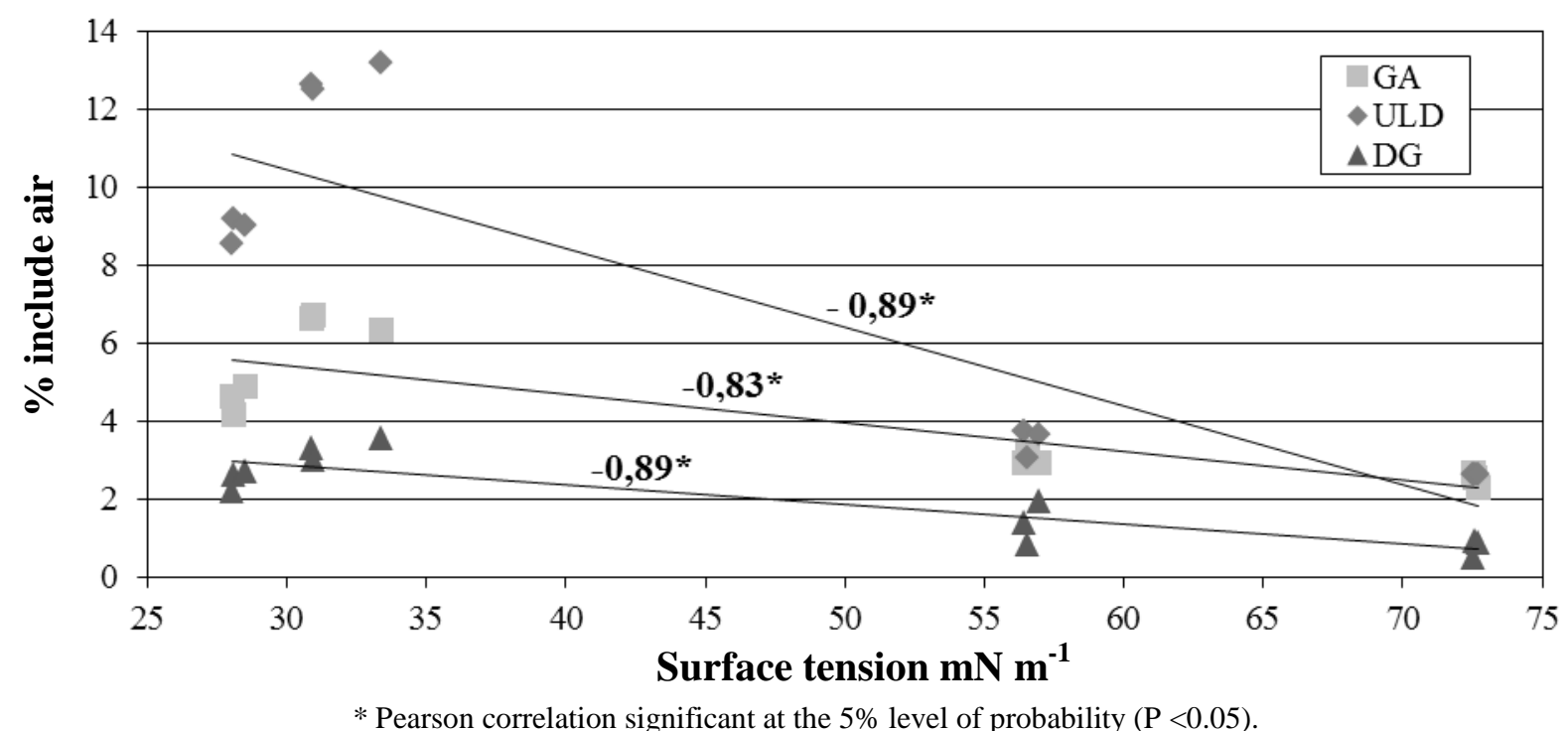

FIGURE 4. Correlation between surface tension (T.S.) and the percentage of air included (\% air) for different spray nozzles.

The major difference that makes the adjuvant Agral has the highest percentage of air included is that, according MILLER \& ELLIS BUTLER (2000), surfactant adjuvant improves the retention of air in the spray to form a homogeneous solution in the solution, which does not occur When oil adjuvant are used due the presence of micelles form an emulsion, which is a heterogeneous mixture. Still, the authors cite that the micelles formed by adjuvant oil, facilitate fragmentation and loss of air inclusions. The lowest percentage of air in the mixture with vegetable oil Nortox can be due to the formation of emulsion (heterogeneous solution). Furthermore, the vegetable oil Nortox has little capability of reducing the surface tension.

\section{CONCLUSIONS}

Adjuvant influences the amount of air that is added in drops generated by spray nozzles.

As a consequence of the different conditions of surface tension generated by the adjuvant, there was a negative correlation between the surface tension and the amount of air which is included in that, the lower the surface tension, the greater the percentage of air included .Besides the surface tension the composition of the adjuvant affects these characteristics, so the water-soluble adjuvant is more likely to increase the amount of air included adjuvant that form emulsion. 


\section{REFERENCES}

ANTUNIASSI, U. R.; BAIO, F. H. R. Tecnologia de aplicação de defensivos. In: VARGAS, L.; ROMAN, E. S. Manual de manejo e controle de plantas daninhas. Passo Fundo: Embrapa Trigo, 2008. p.174-175.

BALAN, M. G.; ABI-SAAB, O.; SILVA, J. G.; RIO, A. Deposição da calda pulverizada por três pontas de pulverização sob diferentes condições meteorológicas. Semina: Ciências Agrárias, Londrina, v.29, n.2, p.293-298, abr.jun. 2008.

BOLLER, W.; RAETANDO, C. G. Bicos e pontas de pulverização de energia hidráulica, regulagem e calibração de pulverizadores. In: ANTUNIASSI, U. R.; BOLLER, W. Tecnologia de aplicação para culturas anuais. Passo Fundo: Aldeia Norte; Botucatu: FEPAF, 2011. P.51-82.

BUTLER ELLIS, M. C.; TUCK, C. R.; MILLER, P. C. H. The effect of some adjuvants on sprays produced by agricultural flat fan nozzles. Crop Protection, Guildford, v.16, n.1, p. 609-615, 1997.

CARVAlHO, F. K.; CHECHETTO, R. G.; VIlELA, C. M.; SILVA, A. C. A.; MOTA, A. A. B.; OLIVEIRA, R. B.; ANTUNIASSI, U. R. Aplicação planejada. Cultivar Máquinas, Pelotas, v. 112, p. 24-26, 2011.

CHECHETTO, R. G.; ANTUNIASSI, U. R. Espectro de gotas gerado por diferentes adjuvantes e pontas de pulverização. Energia na Agricultura, Botucatu, v.27, n.3, p.130-142, jul./set. 2012.

CHRISTOFOLETTI, J. C. Considerações sobre a deriva nas pulverizações agrícolas e seu controle. São Paulo: Teejet South América, 1999. p. 15.

COSTA, E. A. D. Efeito de surfactantes sobre a tensão superficial de soluções de Rodeo. 1997. 84 f. Dissertação (Mestrado em Proteção de Plantas) - Faculdade de Ciências Agronômicas, Universidade Estadual Paulista, Botucatu, 1997.

COSTA, A. G. F.; VELINI, E. D.; NEGRISOLI, E.; CARBONARI, C. A.; ROSSI, C. V. S.; CORREA, M. R.; SILVA, F. M. L. Efeito da intensidade do vento, da pressão e de pontas de pulverização na deriva de aplicações de herbicidas em pré-emergência. Planta Daninha, ViçosaMG, v.25, n.1, p.203-210, jan./mar. 2007.

COSTA, A. G. F.; VELINI, E. D.; ROSSI, C. V. S.; CORRÊA, M. R.; NEGRISOLI, E. FIORINI, M. V.; CORDEIRO, J. G. F.; SILVA, J. R. M. Efeito de pontas e pressões de pulverização na deriva de glyphosate + 2,4-D em condições de campo. Revista Brasileira de Herbicidas, Maringá, v.11, n.1, p.62-70, jan./abr. 2012.

CUNHA, J. P. A. R.; ALVES, G. S.; REIS, E. F. Efeito da temperatura nas características físicoquímicas de soluções aquosas com adjuvantes de uso agrícola. Planta Daninha, Viçosa-MG, v.28, n.3, p.665-672, 2010.

CUNHA, J. P. A. R.; BUENO, M. R. Espectro de gotas de pontas de pulverização com adjuvantes de uso agrícola. Planta Daninha, Viçosa-MG, v.28, p.1153-1158, 2010.

FAGGION, F.; ANTUNIASSI, U. R. Desempenho de pontas de pulverização quanto a indução de ar nas gotas. Energia na Agricultura, Botucatu, v.25, n.4, p.72-82, 2010.

FAGGION, F. Desenvolvimento de métodos para estimar a quantidade de ar incluído às gotas por pontas de pulverização com indução de ar. 2002.73 f. Tese (Doutorado em Agronomia) Faculdade de Ciências Agronômicas, Universidade Estadual Paulista, Botucatu, 2002.

GULER, H.; ZHU, H., OZKAN, H. E.; DERKSEN, R. C.; YU, Y.; KRAUSE, C. R. Spray Characteristics and Drift Reduction Potential with Air Induction and Conventional Flat-Fan Nozzles. Transactions of the ASAE, St. Joseph, v.50, n.3, p.745-754, 2007. 
IOST, A. R. C.; RAETANO, C. G. Tensão superficial dinâmica e ângulo de contato de soluções aquosas com surfatantes em superfícies artificiais e naturais. Engenharia Agrícola, Jaboticabal, v.30, n.4, p.670-680, jul./ago. 2010.

MATTHEWS, G. A. Developments in application technology. Environmentalist, Hampshire, v.28, p.19-24, 2007.

McMULLAN, P. M. Utility adjuvants. Weed Technology, Champaign, v.14, p.792-797, 2000.

MENDONÇA, C. G.; RAETANO, C. G.; MENDONÇA, C. G. Tensão superficial estática de soluções aquosas com óleos minerais e vegetais utilizados na agricultura. Engenharia Agrícola, Jaboticabal, v.27, p.16-23, jan. 2007.

MILLER, P. C. H.; BUTLER ELLIS, M. C. Effects of formulation on spray nozzle performance for applications from ground-based boom sprayers. Crop Protection, Guildford, v.19, p.609-615, 2000.

MONTÓRIO, G. A.; VELINI, E. D.; MACIEL, C. D. G.; MONTÓRIO, T. Eficiência dos surfatantes de uso agricola na redução da tensão superficial. Revista Brasileira de Herbicidas, Maringá, v.4, n.2, p. 8-22, 2005.

OLIVEIRA, R. B.; ANTUNIASSI, U. R. Caracterização física e química e potencial de deriva de caldas contendo surfatantes em pulverizações agrícolas. Energia na Agricultura, Botucatu. v.27, n.1, p.138-149, jan./mar. 2012.

OLIVEIRA, R. B. Caracterização funcional de adjuvantes em soluções aquosas. 2011. 121f. Tese (Doutorado em Agronomia/Energia na Agricultura) - Faculdade de Ciências Agronômicas, Universidade Estadual Paulista, Botucatu, 2011.

PIGGOTT, S.; MATTHEWS, G. A. Air induction nozzles: a solution to spray drift?. International Pest Control, London, v.41, p.24-28, 1999. 